\title{
76- Yeni medya etiği etrafinda üretilen tara-çeviri pratikleri: Kavramsal tartışmalardan saha deneyimlerine
}

\section{Zeynep SÜTER GÖRGÜLER'}

APA: Süter Görgüler, Z. (2021). Yeni medya etiği etrafinda üretilen tara-çeviri pratikleri: Kavramsal tartışmalardan saha deneyimlerine. RumeliDE Dil ve Edebiyat Araştırmaları Dergisi, (25), 11981213. DOI: 10.29000/rumelide.1032577.

\author{
$\ddot{O} \mathbf{z}$
}

Yeni medya ağları çeviri pratiklerini ve çevirmen kimliklerini yeniden üretirken, çeviri etiğine ilişkin kavramları ve yaklaşımları da yeniden yapılandırmaktadır (Fernández-Costales, 2011, 2012; Gambier, 2009; Pérez-González ve Susam-Saraeva, 2012; O’Hagan, 2009). Küreselleşme hareketiyle birlikte Japonya'nın kültürel düzlemde yumuşak gücünü temsil eden, Japonca ve İngilizce kaleme alınan manga yapıtları dijital ağlarda farklı dillere çevrilmektedir. Manga yapıtlarının sanal ortamda yapılan çevirileri, tara-çeviri olarak adlandırılırken, bu içerikleri üreten çevirmenler ise taraçevirmen olarak tanımlanmaktadır. Bu çalışmada, dijital ağlarda şekillenen tara-çeviri pratiklerinin ve tara-çevirmen kimliklerinin yeni medya etiğine ilişkin kavramlar ve yöntemler (Binark ve Bayraktutan, 2013; Niedzvieck, 2010; Uzun, 2013) ışı̆̆ında okunması ve tara-çevirmenlerin bu süreçte inşa ettikleri çeviri etiği hareketinin görünür kılınması amaçlanmaktadır. Saha çalıması kapsamında, farklı tara-çeviri topluluklarında tara-çeviri içeriği (İngilizceden Türkçeye) üreten 5 tara-çevirmenin bu yönde benimsedikleri üretim pratiklerinde, yeni medya etiğine ilişkin kavramların ve yaklaşımların netnografik izleri sürülmektir. Bu çerçevede, ortak iletişim etiği, açık etik yapma, özdenetimsel anlayış, yeni medya okuryazarlı̆̆ ve etik muhakeme becerisi gibi yeni medya etiğine ilişkin kavramlar ve yöntemler etrafında üretilen tara-çeviri pratiklerine ve taraçevirmen kimliklerine dikkat çekilmektedir. Çeviri etiğinin kavramsal dayanaklarını genişleten ve çeşitlendiren bu çalışmada, çeviri alanının yeni medya alanıyla kurduğu disiplinlerarası etkileşime ışık tutulmaktadır. Bununla birlikte, çeviri etiğinde yürütülen kuramsal sorgulamaların, saha deneyimleriyle birlikte yeniden inşa edilebileceği gerçeği araştırma kapsamında tartışmaya açılmaktadır. Sonuç olarak yeni medya etiğine ilişkin kavramsal dayanakların, tara-çeviri pratikleri ve tara-çevirmen kimlikleri üzerindeki yansımalarına odaklanmak, çeviri etiğine ilişkin yeni sorgulamaların ve yeni düşünce biçimlerinin şekillenmesine bir nebze de olsa katkı sağlayacaktır.

Anahtar kelimeler: Manga, tara-çeviri, tara-çevirmen, çeviri etiği, yeni medya etiği

\section{Scanlator identities produced around new media ethics: From conceptual discussions to field experiences}

\begin{abstract}
While new media networks reproduce translation practices and translator identities, they also restructure concepts and approaches related to translation ethics. Along with the globalization movement, the comic art manga which represents Japan's soft power on the cultural plane is translated into different languages on digital networks. While the translations of manga in the virtual environment are called "scanlation", the translators who produce these contents are defined as
\end{abstract}

Arș. Gör. Dr., Yıldız Teknik Üniversitesi, Fen-Edebiyat Fakültesi, Batı Dilleri ve Edebiyatları Bölümü, Fransızca Mütercim ve Tercümanlık ABD (İstanbul, Türkiye), zeynepsuter@gmail.com, ORCID ID: oooo-ooo1-6538-4840 [Araştırma makalesi, Makale kayıt tarihi: 03.11.2021-kabul tarihi: 20.11.2021; DOI: 10.29000/rumelide.1032577] 
"scanlator". In this study, it is aimed to read scanlation practices and scanlator identities shaped in digital networks in the light of new media ethics concepts and methods and to make visible the translation ethics movement built by scanlators in this process. Within the scope of the field study, the netnographic traces of the concepts and approaches related to new media ethics in the production practices adopted by the 5 scanlators who produce scanlation content (from English to Turkish) in different scanlation communities are emphasized. In this framework, attention is drawn to the scanlation practices and scanlator identities produced around concepts and methods related to new media ethics such as common communication ethics, open ethic, self-reflexive understanding, new media literacy and ethical reasoning skills. This study, which expands and diversifies the conceptual foundations of translation ethics, sheds light on the interdisciplinary interaction of the translation field with the new media field. In addition, the fact that theoretical inquiries in translation ethics can be reconstructed with field experiences is also discussed within the scope of the research. As a result, focusing on the reflections of the conceptual foundations of new media ethics on scanlation practices and scanlator identities will contribute to the shaping of new inquiries and new ways of thinking about translation ethics.

Keywords: Manga, scanlation, scanlator, translation ethics, new media ethics

\section{Giriş}

Günümüzde disiplinlerarası etkileşimin sıkça deneyimlendiği bilimsel paylaşım ağlarında, çeviri etiğine yönelik yeni kavramların, yaklaşımların ve yeni ilişkisel üretim alanlarının oluşmasına ihtiyaç duyulmaktadır. Bu çerçevede, yeni medya ağlarına ilişkin kavramsal değişkenlerin ve söylemlerin çeviri etiğini yeniden inşa ettiği belirtilebilmektedir. Bu araştırmada², ağlar kuran tara-çeviri pratiklerine ve tara-çevirmen kimliklerine odaklanarak, çeviri etiğine ilişkin kavramlara ve uygulamalara yeni bir soluk kazandırılması amaçlanmaktadır. Bir başka deyişle, yeni medya ağlarında üretilen tara-çeviri pratiklerinin etik sonuçlarını tartışmaya açarken, var olan çeviri etiği yaklaşımlarının ötesine geçilmesi ve bunlara yeni medya etiği kapsamında açılım kazandırılması çalışmanın hedefleri arasında yer almaktadır. Araştırmanın birincil kavramlarına yakından bakıldığında, tara-çeviri3 (ing. "scanlation”), manga yapıtlarının (Japonca ve Ingilizce), internet temelli iletişim ağlarında taranıp, farklı dillere çevrildikten sonra dolaşıma sokulan çevrimiçi versiyonlarıdır (Rampant, 2010: 226) (bkz. Şekil 1).

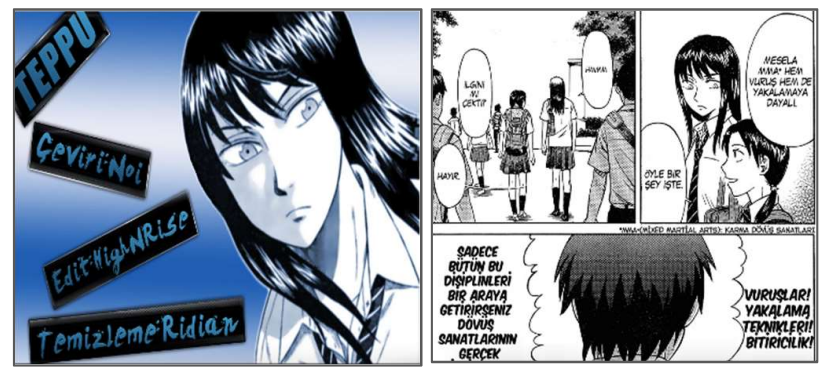

Şekil 1. Teppu başlıklı tara-çeviri içeriği (http://bato.to/reader\#72fog178c4f63a16_39)

\footnotetext{
2 Bu çalıșma, Yıldız Teknik Üniversitesi, Sosyal Bilimler Enstitüsü, Diller ve Kültürlerarası Ceviribilim Doktora programında, Prof. Dr. Z. Emine Bogenç Demirel danışmanlığında yürütülmüş olan "Yeni Toplumsallıklar Etrafinda Yükselen Çeviri Pratikleri: Türkiye’de Tara-Çeviri (Manga) İçeriklerinin Dolaşımı ve Netnografik Çözümlemeler” (2016) başlıklı doktora tez çalışmasından üretilmiştir.

3 Scanlation, scanlator ve scanlation community kavramları, araştırmanın yazarı tarafından Türkçeye sırasıyla tara-çeviri,
} tara-çevirmen ve tara-çeviri topluluğu olarak çevrilmiştir. 
Tara-çeviri toplulukları (ing. "scanlation communities"), ekonomik çlkar beklemeksizin, gönüllülük ilkesinden hareketle yeni medya ortamlarında tara-çeviri içeriği üreten çevrimiçi topluluklardır (Rampant, 2010: 227). Tara-çevirmen (ing. "scanlator") ise tara-çeviri topluluklarında, farklı dillerde tara-çeviri içerikleri üreten, ardından bunları dijital ağlarda dolaşıma sokan ve tüketen gönüllü internet kullanıcısıdır. Dijital ağlarda manga yapıtlarının çevirisini yapan ve bunları dolaşıma sokan taraçevirmenler sırasıyla aşağıda yer alan aşamaları deneyimlemektedirler (Rampant, 2010: 228):

- Orijinal manga yapıtlarının (İngilizce veya Japonca) taranmış çevrimiçi formatlarına (ing. "manga raw") ulaşmak,

- Balon ve balon dışı içerikleri temizlemek,

- Arka planı düzenlemek, renkleri ayarlamak ve çözünürlüğü arttırmak,

- Orjinal içeriği çevirmek ve çevirisi yapılan içerikleri balonlara yerleştirmek,

- Dizgiyi gerçekleştirmek,

- Düzenleme programları aracılığıyla biçimsel ve içeriksel son kontrolü sağlamak,

- Tara-çeviri içeriğini siteye yüklemek ve servis etmektir.

Japon çizgi roman sanatını tanımlayan manga sözcüğü "sorumsuz resim” anlamına gelmektedir. Manga kavramı sadece çizgi roman türünü kapsamamakla birlikte, Japonya'da üretilen çizgi romanları altında toplayan şemsiye kavram olarak anlam kazanmaktadır. Kökenleri Japon kültürüne dayalı, çevirisi, basımı ve dağıtımı yapılan her türlü çizgi romanı içinde barındıran manga kavramı, bu çizgi romanların oluşturduğu alt kültürü simgeleyen sanat akımının adıdır. Yirminci yüzyılın ikinci yarısından sonra, manga gittikçe gelişerek, çeşitlenerek ve gerçek formunu bulmaya başlayarak küresel eksende diğer toplumların dikkatini çekmiş ve halen de çekmeye devam etmektedir. Bu nedenle özellikle ikinci dünya savaşından sonraki dönem, modern manganın doğuşu olarak kabul edilmektedir (Aydın, 2007: 9). Mangalar kendi içlerinde çeşitli yaş grupları ve toplumsal konumlar göz önünde bulundurularak üretilmektedir. Bu bağlamda, çocuklar, genç kızlar, genç erkekler, ev kadınları, genç anneler, çalışan erkekler, yaşlılar vb. diğer toplumsal kesimlere hitap eden manga eserleri yaratılmaktadır. Manga eserlerini diğer çizgi roman türlerinden ayrıştıran nitelikleri "mangakalar" (manga yazan çizen sanatçlar) tarafından başvurulan kurgusal temalar ve kullanılan çizim teknikleridir. Modern manga eserlerinde gündelik hayatla ilişkili olan toplumsal meselelere odaklanılmaktadır. İlk zamanlardan beri Japonların coğrafi anlamda deniz aşırı bir konumda yer almaları sonucunda dışarıya kapalı bir toplum olarak kendi iç dünyalarında yaşamış olmaları ve bununla birlikte Ikinci Dünya Savaşının son bulmasıyla karşı karşıya kaldıkları ekonomik, siyasi ve sosyo-kültürel bunalım döneminin bireysel anlamda dişavurumu çağdaş manga eserlerinde vurgulanan konu çeşitliliğini desteklemektedir (Aydın, 2007: 12). Paul Gravett’in deyimiyle, “Japon ruhuyla, Batı tekniğinin sentezi sonucunda gelişen, Doğu'yla birleşen Batı ve eskiyle birleşen yeninin karışımından ortaya çıkan tür olarak kavramsallaştırmak mümkündür manga eserlerini” (Gravett, 2008: 18). Japonya’nın küresel düzlemde "yumuşak gücünü” temsil eden manga yapıtlarının ithalatının bu denli büyük hacimlere ulaşmasının arkasında yatan nedenler, manganın küresel başarısını açıklar niteliktedir. Manga bir yandan Batı toplumunda tabulaşmış öğeleri yıkarak batılı değerleri sarsmakta, diğer yandan ise Batıyla Doğunun kesiştiği noktada "melez" yapısıyla küresel bir ürün olarak ortaya çıkmaktadır (Bouissou, 2006: 151). Kökenleri Japon-Çin felsefesine ve mitolojisine kadar uzanan mangalar, zaman içerisinde küreselleşme 
hareketinin yarattığı teknolojik gelişmelerle birlikte yeniden yapılanma sürecine girmişlerdir. JaponAmerikan ortaklığıyla kurulan birçok yayınevi, orijinal mangaları çevirip anyı anda hem e-kitap formatında, hem de normal cilt şeklinde piyasaya sürmekte ve web sitelerinden satış yapmaktadırlar. Küresel düzlemde manga çevirilerine duyulan yoğun istek sonucunda arzın talebi karşılamakta yetersiz kalması, manganın dijital ortamda gönüllü kullanıcılar tarafından farklı dillere çevrilmesini ve dijital ortamda dolaşıma sokulmasını beraberinde getirmektedir.

Tara-çeviri pratiklerinin etik sonuçlarını gündeme getiren bu çalışmanın vurgu noktaları şu şekilde ifade edilebilmektedir:

- Dijital ağlarda şekillenen tara-çeviri pratiklerini ve tara-çevirmen kimliklerini, yeni medya etiğine ilişkin kavramlar ve yöntemler ışığında okumak;

- Netnografik saha çözümlemesi ışı̆̆ında, yeni medya ortamlarında tara-çevirmenlerin nasıl bir çeviri etiği hareketi inşa ettiklerini kavramaktır.

Araştırma örnekleminde 5 tara-çevirmen yer almaktadır . Tara-çevirmenlerden her birine farklı bir kod atanmıştır 5 . Bu çerçevede, tara-çevirmen 1 ve tara-çevirmen 2 AnimeMangaTR topluluğunda, taraçevirmen 3 Soutensubs topluluğunda, tara-çevirmen 4 Tortuga topluluğunda, tara-çevirmen 5 ise MangaFrame topluğunda tara-çeviri içerikleri üretmektedirler. İlgili tara-çevirmenler İngilizce kaleme alınan mangaları Türkçeye çevirmektedirler.

Netnografi, internet ağı üzerinde etkileşimde bulunan çevrimiçi toplulukların pratiklerine ve davranış biçimlerine yönelik çevrimiçi metin temelli yürütülen çözümleme yöntemidir (Kozinets, 2006: 280281). Netnografik veriler, içerik çözümlemesi, söylem çözümlemesi ve tematik çözümleme gibi niteliksel araştırma yöntemleriyle çözümlenmekte ve bunun sonucunda ortaya çıkan bulgular yorumlanmaktadır (Binark, 2014). Saha çalışması kapsamında, ilgili tara-çevirmenlerin geliştirdikleri üretim pratiklerinin ve performans sergileme biçimlerinin etik sonuçları netnografik çözümleme ışığında ele alınmaktadır.

Netnografik saha çalışması çerçevesinde ilgili tara-çevirmenlere benimsedikleri çeviri etiği yaklaşımlarını betimlemek üzere aşağıda yer verilen sorular yöneltilmektedir:

> Yeni medya etiği perspektifinden baktığınızda, tara-çeviri içeriklerinin üretim ve tüketim süreçlerine yönelik bakış açınız nedir?

$>\mathrm{Bu}$ süreçlere yönelik deneyimlediğiniz etik sorunsallar ve bunları tetikleyen koşullar hangileridir?

> Deneyimlediğiniz etik sorunlar karşısında, ne tür müdahaleler, kimler tarafından yapılmalıdır?

Elde edilen yanıtlar ışı̆̆ında, ilgili tara-çevirmenlerin üretim pratiklerinde ve performans sergileme biçimlerinde, "ortak iletişim etiğì", "açık etik yapma”, "özdenetimsel anlayış", "yeni medya okuryazarlığı” ve "etik muhakeme becerisi” gibi yeni medya etiğine yönelik kavramların ve yöntemlerin netnografik izleri sürülmektedir. Bununla birlikte, çeviri etiğinin kavramsal dayanaklarını genişletmeyi

\footnotetext{
4 Saha çalışması çerçevesinde çözümlenen netnografik veriler 2016 yllında toplanmıştır. İlgili tara-çevirmenlerin onanmış rızaları ilgili tez çalışması (Görgüler, 2016) kapsamında alınmıștır.

Tara-çevirmen 1, tara-çevirmen 2, tara-çevirmen 3, tara-çevirmen 4 ve tara-çevirmen 5 sirasıyla T.Ç. 1, T.Ç. 2, T.Ç. 3, T.Ç. 4 ve T.Ç. 5 olarak kodlanmıştır.
} 
ve çeşitlendirmeyi hedefleyen bu çalışmada, çeviri alanının yeni medya alanıyla kurduğu disiplinlerarası etkileşimin görünür kılınması hedeflenmekte ve bu doğrultuda çeviri etiğinde kuram-uygulama ilişkiselliğinin, saha deneyimleriyle birlikte yeniden inşa edilebileceği gerçeği gündeme taşınmaktadır. Yeni medya etiğine ilişkin yaklaşımların, tara-çeviri pratikleri ve tara-çevirmen kimlikleri üzerindeki yansımalarını çözümlemek, çeviri etiğine ilişkin kavramsal ve yöntemsel repertuvar odă̆ında yeni sorgulamaların ve yeni düşünce biçimlerinin şekillenmesine destek olacaktır.

\section{Kavramsal ve yöntemsel çerçeve}

\subsection{Yeni medya etiği: Olanaklar ve tehditler}

Yeni medya teknolojileri etrafında üretilen ve kullanıcı türevli içerik üretimini destekleyen sosyal medya ağları, toplumsal ve bireysel düzlemde kurulan iletişim pratiklerini yeniden inşa etmektedir. $\mathrm{Bu}$ çerçevede, yeni medya ağlarında üretilen kültürel üretim eylemlerinin ve sonuçlarının etik meselesi çerçevesinde ele alınması gerekliliği öne çıkan bir gerçekliktir. $O$ halde, dijital deneyimler çerçevesinde benimsenen yeni medya etiğine yönelik kavrayış hangi ilkelere dayanmaktadır? Bu bağlamda, dijital içeriklerin dolaşımında ortaya çıkan sorunsallar nelerdir? Bu süreçte, sorumlu taraflar kimlerden oluşmaktadır ve sunulan çözüm önerileri nelerdir?

Kültürel üretim alanı olarak deneyimlenen dijital ağlarda, kullanıcı bir yandan ifade özgürlüğü ve bilgiye erişim hakkını kullanabilmekte, diğer yandan ise mahremiyetin ve özel hayatın ihlali gibi etik sorunlarla karşı karşıya kalmaktadır. Başka bir deyişle, yeni medya ortamları ve uygulamaları, bir yanıyla kullanıcıya sınırsız bilgiye ulaşma özgürlüğü tanıyıp, kullanıcıların kendi düşüncelerini bu gibi ortamlarda diğer kullanıcılara ulaştırmalarına fırsat tanırken, diğer yanıyla aynı özelliklerin etkisiyle ırkçı ve nefret öğesi barındıran içeriklerin dolaşımında rol oynayabilmektedir.

Hal Niedzvieck (2010) yeni medya ve iletişim araçlarının, bireyin toplumsal ve kültürel alglarını dönüştürdüğünü ve yeniden ürettiğini dile getirmektedir. Niedzvieck'e göre, "insan yaşamının dijitalleşmesi ve elektronik ortamlara kayması sonucunda gelişen dikizleme kültürü, içinde hem ultra bireyselciliği hem de kapitalizmin tohumlarını ve en önemlisi de yitirilmiş topluluk duygusuna duyulan özlemi içinde barındırmaktadır" (2010: 244). Bununla birlikte, yazar, "bireyin, başkalarıyla iletişim kurmak için kişisel bilgilerini sosyal paylaşım platformlarında abartılı bir şekilde paylaşıyor olması sonucunda, internet ağlarının özel alan ve kamusal alan arasındaki sınırlara geçirgen bir nitelik kazandırdığını" sözlerine eklemektedir (2010: 245).

Yeni medya etiği, "yeni medya ağlarında ortaya çlkan etik sorunlar ve bu sorunlara yönelik farkındalık olarak anlam kazanmaktadır" (Binark ve Bayraktutan, 2013: 25). Yeni medya etiği alanı, "kitle iletişim araçlarının işleyişi, daha özelde ise kitle iletişim araçları yoluyla yayılan enformasyonla ilgili olarak ortaya çıkan sorunlu durumlar hakkında sistematik bir düşünce biçimi sunmaktadır" (Binark ve Bayraktutan, 2013: 26). Yeni medya olgusu etik meselelerden ayrı ele alınamayacağı gibi, "iletişim ağlarının yönetim konusu, teknolojinin tasarlanacağı biçimden, bu teknolojiyi kimlerin nasıl ve ne kadar kullanacağının belirlenmesine kadar değişen durumlarda kararlar alınmasını ve etik seçimler yapılmasını içermektedir"(Uzun, 2013: 8).

Yeni medya ağlarında deneyimlenen etik sorunlar çeşitlilik göstermektedir. Yeni medya içeriklerinin dolaşımını ve üreten tüketici konumundaki eyleyicilerin bu yöndeki üretim pratiklerini tehdit eden koşulları gündeme taşımak oldukça önemlidir. Bu çerçevede, "özel yaşamın gizliliğinin ihlal edilmesi, 
telif ve patent haklarının çiğnenmesi, içeriğin asıl kaynağının gösterilmemesi, üretilen içeriklerin olgunlaşmadan ve doğruluğunun teyit edilmeden yayılması, içeriğe yönelik yanlış ve yanıltıcı başlıklandırma ve etiketleme yapılması, veri madenciliğinin ve dijital gözetiminin yaygınlaşması ve kişisel verilerin güvenliğinin sağlanmaması" gibi etik sorunsallar yeni medya temelli üretim ağlarında öne çıkmaktadır (Binark ve Bayraktutan, 2013: 38-39).

Yeni medya içeriklerinin dolaşımını tehdit eden etik sorunların kültürel ve ekonomik nedenleri bulunmaktadır. Ekonomik nedenler çerçevesinde, "internet ağının egemen güçler tarafından ticari ve kapitalist bir araç olarak kullanılması” örnek olarak verilmektedir (Binark ve Bayraktutan, 2013: 116). Bununla birlikte, yeni medya ortamlarında, "kullanıcının kişisel haklarını koruma ve kullanma konusundaki bilinç eksikliğı" ortaya çıkan kültürel nedenlere işaret etmektedir (Binark ve Bayraktutan, 2013: 120). Bu nedenle yeni medya uygulamalarında yaşanan etik sorunlara yönelik ne tür müdahalelerin, kimler tarafından yapılacağına ilişkin tartışmalar giderek önem kazanmaktadır.

Yeni medya etiği konusuyla ilgili bütün tarafların dahil olacağı "ortak iletişim etiği” yaklaşımı öne çımaktadır (Binark ve Bayraktutan, 2013: 157). Bir başka deyişle, bütün aktörlerin -devlet kurumlarının, yayınevlerinin, hukukçuların, sivil toplum örgütlerinin- müdahalelerinin alanın içinde tutulmasıyla birlikte etik anlamda sorumluluğun çok katmanlı ve çok aktörlü olduğu gerçeği göz önünde bulundurulmalıdır. Bu noktada, "açı etik yapma" pratiğinin önemini vurgulamak yerinde olacaktır. Aynı zamanda, "herkesi kapsayan, toplulukla birlikte yaşama konusuna vurgu yapan bir bakış açısının, yeni medya ortamları üzerine geliştirilecek olan etik yaklaşımda etkili olması kaçınılmaz bir gerekliliktir" (Binark ve Bayraktutan, 2013: 158).

Bireysel üretimin anlam kazandığı yeni medya ağlarında, bireyin özdenetimsel pratikler geliştirmesi etik sorunlar karşısında çözüm sunabilmektedir. Bu bağlamda, "bireyin güçlendirilmesi, yeni medya ortamında karşılaştığı etik sorunların çözümünde etkili olabilmesi için çeşitli bilgi ve becerilerle donatılmış olması gerekmektedir" (Binark ve Bayraktutan, 2013: 150). Bireye bu doğrultuda kazandırılacak olan bilgiler, beceriler ve yetiler, "eleştirel yeni medya okuryazarlığı" kavramı etrafında etrafında şu şekilde tanımlanmaktadır (Binark ve Bayraktutan, 2013: 156):

\begin{abstract}
"Yeni medya okuryazar olan birey kamusal, sivil ve siyasal alanlarda bireysel ve kolektif olarak fikirlerini daha iyi bir şekilde açıklayabilir, pazar yönelimli ekonomide kendinin salt tüketici olarak konumlandırılmasın önleyecek şekilde enformasyonu kullanabilir ve nitelikli enformasyon kaynaklarma ulaşabilir, yeni medya ortamlarmda etik ihlallerde bulunmaz ve etik ilkelere uygun davranabilir. Bir başka deyişle, yeni medya okuryazarı olan bireyin internette risk yaratabilecek çeşitli niteliksiz ve/veya sakıncal içeriklere erișim konusunda bir çeșit farkındalıkla donanmış olması ve bu içeriklere erişmemesi, aracın ve ortamın iletişim sürecindeki dolayımlayıcı niteliğinin farkında olması beklenebilir.”
\end{abstract}

Yeni medya okuryazarlığı, kullanıcıya yeni medya ortamlarını deneyimlerken karşılaşacağı sorunlar karşısında benimseyeceği etik tutuma ilişkin yol haritası çizmektedir. Buradaki amaç, "bu doğrultuda ortaya çıkacak etik sorunları en aza indirgeyerek, bu türden web 2.0 temelli iletişim ortamlarında, bireyin güçlenmesini sağlamak ve en önemlisi de, çeşitli sorunlar karşısında bireyin özdenetime dayalı etik muhakeme becerisini kazanmasını hedeflenmektedir" (Binark ve Bayraktuan, 2013: 158). Yeni medya okuryazarlığı, bireyin deneyimlediği ortama ilişkin farkındalık ve bilinçli üretim ve tüketim becerisi geliştirmesine destek olmaktadır. Aslına bakılırsa, "yeni medya okuryazarlığı bireyin çevrimiçi olanaklardan yararlanmasını, çevrimiçi risklere karşı da donanımlı olmasını sağlarken, çevrimiçi olanaklardan da en etkin şekilde yararlamasının yolunu açmaktadır" (Binark ve Bayraktutan, 2013: 153) $\mathrm{Bu}$ çerçevede, "etik eğitiminin, yaşamboyu eğitim sürecinin bir parçası olması gerektiği ve eğitimde bu 
yönde bir açlımın demokratik değerlerin içselleştirilmesine yönelik kanallar açacă̆ı” gerçeği de göz önünde tutulması gereken bir husustur (Binark ve Bayraktutan, 2013: 149).

\subsection{Yeni medya ağlarında yeniden yapılanan çeviri etiğí}

Dijital açılımla birlikte ağlarda yapılanan yeni iletişim pratikleri, çeviri pratiğini ve çevirmen kimliğini sosyal medya ortamlarında yeniden inşa etmektedir. Bu çerçevede, çeviri alandaki teknolojik dönüşümün toplumsal sonuçlarını görünür kılan, "katılımcı, paylaşımcı çeviri 2.o hareketleri, kullanıcı türevli çeviri içerikleri, fan, gönüllü, angaje, pro-am çevirmen kimlikleri” (O’Hagan, 2011, 2016; Dolmaya, 2012), "adhokratik çeviri toplulukları" (Pérez-González, 2010; Pym, 2014) ile "demokratik değer yaratma hareketi olarak çeviri” (Demirel ve Görgüler, 2015, 2020) gibi kavramlar ve yaklaşımlar önem kazanmaktadır. Çeviriyi yeniden üreten algoritmalar sonucunda, çok yönlü çevirmen pratiklerinden ve çok kimlikli çevirmen profillerinden bahsetmek mümkündür. Bu çerçevede, yeni medya ağlarında yeniden yapılanan çeviri etiği, çevirmenlik mesleği, çeviri ürünün kalitesi ve çeviri alanının bilimsel itibarı gibi değişkenler etrafında tartışılmaktadır.

Çeviri alanındaki dijital açılımın etik sonuçlarını değerlendiren Alberto Fernández Costales, "dijital çeviri topluluklarına yönelik yargısız infaz uygulamak yerine, bu yeni oluşumları ve ilgili aktörleri içine alacak saha çalışmalarının gerçekleştirilmesinin, onların yarattıkları fırsatları ve tehditleri kavramak açısından eleştirel bir çerçeve sunacağını" belirtmektedir (2012: 18). Bu doğrultuda geliştirilecek olan yaklaşımlar, "profesyonel, fan ve amatör çevirmenler arasında sinerji yaratılmasını desteklemekte ve dijital çeviri topluluklarının bilimsel bir platformda değerlendirilmesine imkan tanımaktadır" (Fernández-Costales, 2012: 19). Dijital çeviri topluluklarının, toplumsal alana yönelik iyileştirici etkilerini de gündeme taşıyan yazar, "katılımcı ve paylaşımcı çeviri pratiklerinin, güç ilişkilerinden doğan dillerarası olduğu kadar kültürlerarası uçurumu da en aza indirgediğinin” altını çizmektedir (2012: 20). Bu yönde gelişen çeviri pratikleri, "unutulan kullanıcılar ile birlikte unutulan dilleri ve bu yöndeki topluluk temelli kültürel üretim pratiklerini görünür kılmaktadır" (Fernández-Costales, 2012: 21). Örneğin, küresel düzlemde az konuşulan diller olarak tanımlanan dil ailelerine mensup toplulukların bilgiye serbest erişim konusunda karşılaştıkları engeller, bu doğrultuda gelişen topluluk odaklı çeviri pratikleriyle aşılmaktadır. Bilginin üretim ve dolaşım sürecinde, Ingilizcenin diğer diller üzerindeki hakimiyetinden doğan dilsel bariyerler, bilişim çağının öne çıkan "açık erişim" ilkesiyle yıkılmaktadır. Bu bağlamda, "bilgiye özgür erişim ve bilgiyi serbest kullanım hakkı yönünde gelişen fırsat eşitliği, çeviri etrafında şekillenen topluluk temelli üretim hareketleriyle yaratılmaktadır" (Fernández-Costales, 2012: 20). Çevirmenlik mesleğinin itibarı konusunu da gündeme taşıyan Fernández-Costales, "yirmi birinci yüzyılda, çevirmen kimliğine yönelik daha kapsamlı bir tanımın geliştirilmesi” gerektiğini ifade etmektedir (Fernández-Costales, 2012: 22). Ağlar üzerine kurulu heterojen çalışma alanı, çevirmenin üstlendiği toplumsal sorumluluk bilinci ile farklı deneyimler kazanmasını zorunlu kılmaktadır. Bu nedenle, "çevirmenin, çok yönlü mesleki kimliğinden ve gönüllüğe dayalı üretim pratiklerinden söz etmek, bu doğrultudaki mesleki etik tartışmaları yeni kavramlar odağında yeniden inşa etmektedir" (Fernández-Costales, 2012: 23).

Teknolojik gelişmelerin çeviri alanındaki etik yansımalarına odaklanan bir diğer araştırmacı Yves Gambier, "çevirmenin dillerarası ve medyalararası iletişimi sağlayan aracı" konumuna dikkat çekmektedir (2009: 5). Yazar, yeni medya ağlarında biçimlenen çoklu çevirmen kimliklerini ve çok yönlü çeviri pratiklerini etik kavramından hareketle yeniden sorgulamaktadır. Çünkü çevrimdışı çeviri hareketlerine yönelik benimsenen etik değerler, ağlarda şekillenen çeviri pratiklerini anlamlandırmakta

Aksi belirtilmediği takdirde çeviriler çalışmanın yazarı tarafından yapılmıştır. 
yetersiz kalmaktadır. Etik anlamda katı kurallar ile yol alınamayacağını belirten araştırmacı, ister amatör olsun ister profesyonel, çevirmenin kendi üretim pratiklerine ilişkin“özdüşünümsel” anlayış geliştirmesi ve aynı zamanda "üst bir bakış” edinmesi, bu doğrultuda çevirmenin etik bir davranış biçimi sergilemesine yardımcı olmaktadır. Çevirmenin çalışma koşullarına eleştirel yaklaşması, karşılaşacağı firsatlar ve riskli durumlar ile yüzleşmesi için çeviri sürecinin her aşamasında "eleştirel bir bakış açısı" geliştirmesi bu yönde çözüm sunabilmektedir (Gambier, 2009: 15).

Luis Pérez-González ve Şebnem Susam-Saraeva, "bilginin serbest dolaşımını sağlayan gönüllü çevirmenlerin, kültürlerarası diyalog ortamını güçlendirdiklerini, böylece farklı toplumlar tarafından bilginin erişilebilir ve ulaşılabilir kılınması için bireylerarası firsat eşitliğini sağladıklarını" ifade etmektedirler (2012: 152). Araştırmacılar, gönüllü çeviri pratiklerinin görünürlük kazanması gerektiğini, kuram-uygulama ilişkiselliği üzerinden dile getirmektedirler (2012: 149):

“Günümüzde, profesyonel anlamda eğitim almayan çevirmenler durdurulamayan bir hıla, geniş bir çalışma alanında ve değişik biçimlerde çeviri yapmaktadırlar. Bu çalş̧malar, profesyonel çeviri hareketlerinin basit birer alternatifleri değildir. Bunlar klasik çeviri hareketlerinden ayrışan yönleriyle, henüz çeviribilim alanı tarafindan hakkettikleri ilgiyi göremeyen ancak incelenmeye değer farklı araştırma konulardır."

Alandaki araştırmacıların, yeni çeviri pratiklerini kontrol altına alma ya da göz ardı etme alışkanlıkları ve bu yeni çevirmenleri "mesleki yeterlilikler" çerçevesinde yetersiz görmeleri ve ortaya çıan ürüne yönelik sadece "kalite kontrol mekanizması" geliştirmeleri, alan içerisindeki ötekileştirmeye eğilimli, bilimsel değerlendirmeden uzak algının varlığına işaret etmektedir. Alan içerisindeki bütünlüğü, ve birlikteliği sekteye uğratan bu yöndeki anlayışlar kırıldığı takdirde, "çeviribilimciler, çevirmenlik mesleğinin, bilimsel ve toplumsal yönde gelişmesi ve görünürlük kazanması açısından bir adım daha atmış olacaklardır" (Pérez-González ve Susam-Saraeva, 2012: 158).

Amatör çevirmenler tarafından çevrilen içeriklerin etik sonuçlarını değerlendirmek üzere herhangi bir "ölçme değerlendirme" ölçütünün bulunmadığı Fernández-Costales (2011) tarafından da belirtilmektedir. Çeviribilim alanında, "çeviri ürünlerin kalitesi” söz konusu olduğunda, tartışmalar genellikle doğru ve/veya yanlış çeviri gibi kavramlar etrafında şekillenmektedir. Fan çevirilerine yönelik kalite odaklı değerlendirme sürecinin sonucunda, dil boyutunda ortaya çıkan hatalar sebebiyle ilgili içeriklere yakıştırılan "düşük kalite çeviri ürünler" etiketi, bu yönde sürdürülen geleneksel "eşdeğerlilik” tartışmalarını yeniden gündeme getirmektedir. Kullanıı türevli çeviri hareketlerinde, örneğin, manga çizgi romanlarının Japoncadan Ingilizceye fanlar tarafından çevrimiçi uygulamalarda gerçekleştirilen çevirilerinde, kullanıcının beklentisi (dilbilgisi, imla vb. dilsel unsurların) "hatasız" bir içerik okumanın bir adım ötesindedir. Fan okur tarafından, kültürel öğelere ve Japon kültürüne özgü yansımalara ilişkin "yabancılığın korunduğu", kaynak yapıtın ruhunun yansıtıldığı çeviri içerikler talep edilmektedir. Bu koşullarda, fan temelli çeviri hareketlerinde, kalite yerine çeviri ürünlerin yüksek düzeyde "yaylım” ve "dolaşım” hızını yerine getirmeleri, fan okur tarafından tercih edilmektedir. Bu nedenle, araştırmacılar kadar profesyonel çevirmenlerden de, çeviri pratiğini yönlendiren yeni koşullara odaklanmaları ve üretilen içeriklerin "kalite" olgusu kapsamında değerlendirilmesi için "alımlama" çalışmalarına dayanan ölçütler belirlemeleri beklenmektedir (2011: 5).

Kullanıcı türevli çeviri hareketlerinin "hukuksal” boyutunu ele alan Minako O’Hagan (2009), anime, manga ve oyun gibi benzer içeriklere yönelik çevrimdışı piyasada satışa sunulan resmi çevirilerin hemen ardından, fan çevirmenlerin kendi ürettikleri içerikleri çevrimiçi ortamdan geri çekmelerinin bu yönde uygulanan cezai yaptırımları hafiflettiğini belirtmektedir. Kullanıcı türevli çeviri pratiklerine yönelik oluşan etik algının, "dijital korsanlık, telif haklarının ihlali ve dijital emek hırsızlı̆̆ı" gibi kavramlara 
odaklanması, internet ağının "gönüllü paylaşıma, katılıma ve işbirliğine" dayalı üretim felsefesiyle çelişmektedir. Profesyonel üretim pratiklerinin yerini alan "maddi olmayan emek" ve ileri düzeyde "alan bilgisi", fan çevirmenleri çevrimiçi kültürel üretim alanında "meşru" bir zemine taşımaktadır. Bu yöndeki hareketlerin bilimsel tartışmalara konu olması demek, çeviri alanında hem kuramsal hem de uygulamalı düzlemde "yapıcı" bakış açılarının ve "eleştirel” yaklaşımların yeniden üretilmesi anlamına gelmektedir. Çünkü bu yöndeki hareketlere ilişkin etik düzlemde yanıt bulmayı bekleyen sorular varlığını korumaktadır. Çevirmenlik mesleği sürdürülebilir niteliğini korumak için yeni dünya düzeniyle yüzleşmek durumundadır. Dışarıdan içeriye sızan yeni hava akımı sayesinde, mesleki anlamda çevirmen kendini yeniden yapılandırmaktadır. Aksi halde elektronik ağların başlattığı toplumsal dönüşüm sürecini göz ardı etmek, çevirmenin atıl çalışma koşulları içerisine gömülmesine ve bunun soncunda yok olup gitmesine neden olacaktır. Bu nedenle çevirmenin sağa sola sapmalar ile bakış açısını değiştirmesi sonucunda, bilmediğini değersiz kılma yönündeki davranış biçiminden sıyrılması, benliğinde yaşadığı, "profesyonel-amatör" çatışmasından doğan "gerilimi" dindirecektir. (2009: 115-116).

Görüldüğü üzere, fan, amatör ve profesyonel olmayan çevirmenlerin ürettiği pratikleri çevreleyen etik değerler, çeviri içeriklerin kalitesini, çevirmenin mesleki görünürlüğünü ve çeviri alanının itibarını konu alan değişkenler etrafında tartışılmaktadır.

\section{Netnografik saha çözümlemesi: Tara-çevirmenler ve yeni medya etiği}

Araştırma örneklemini oluşturan tara-çevirmenlere benimsedikleri çeviri etiği yaklaşımlarını betimlemek üzere yöneltilen soruların yanıtlarına geçmeden önce, ilgili tara-çevirmenlerin yer aldıkları topluluklara ve bu topluluklarda üstlendikleri görevlerine ilişkin bilgiler ile rumuzlarını ve avatarlarını içeren dijital kimliklerine yönelik veriler aşağıda yer almaktadır (bkz. Tablo 1):

\begin{tabular}{|c|c|c|c|c|}
\hline $\begin{array}{l}\text { Tara-Çeviri } \\
\text { Topluluğu }\end{array}$ & Rumuz & Avatar & Görev & Kod \\
\hline \multirow{2}{*}{ AnimeMangaTR } & Bakayalo & & Çevirmen ve redaktör & T.Ç. 1 \\
\hline & Defir8o & - & Editör & T.Ç. 2 \\
\hline Soutensubs & IMC & & Moderatör ve çevirmen & T.Ç. 3 \\
\hline Tortuga & NiTian ErXing & & Editör ve çevirmen & T.Ç. 4 \\
\hline MangaFrame & Thiefpliskin & & Çevirmen & T.Ç. 5 \\
\hline
\end{tabular}

Tablo 1. Tara-çevirmenlere ilişkin bilgiler

\subsection{Yeni medya etiğinin kavramsallaştırılması üzerine}

İlk soru kapsamında, tara-çevirilerin üretim ve tüketim süreçlerine ilişkin tara-çevirmenlerin zihinlerinde oluşan etik kavrayış üzerinde durulmaktadır. Bu kapsamda, ilgili tara-çevirmenler ürettikleri tara-çeviri içeriklerine yönelik geliştirdikleri etik yaklaşımlarını, "ekonomik çıkarın 
gözetilmemesi”, “açık erişim ilkesi”, "kültürlerarası diyalog ağları” ile "çevrimiçi ve çevrimdışı üretim ilişkiselliği” gibi farklı vurgu noktaları odağında tanımlamaktadırlar. Bu çerçevede, 1 numaralı taraçevirmen, tara-çeviri pratiğinin gönüllüğe dayalı bedelsiz olduğu gerçeğini şu şekilde dile getirmektedir:

"Internet ortamında manga çevirisi, editi yapan kişiler, telif hakkın ihlal ettiklerinden dolayı vicdan azabı çekmezler. Bu yalnızca Türkiye'de değil, dünyanın her yerinde böyledir [...]. Onun dışındaki tüm siteler korsandır ama bunun adına korsan yayın denmez. Manga çeviri işi, niteliği itibariyle kamu hizmetine yakn bir türdür. Belli bir kitleye hitap eder, bedelsizdir, gönüllülük esastır [...].” (T.Ç. 1)

Bir diğer tara-çevirmen bu süreçte ekonomik çlkar gözetmediklerine vurgu yapmaktadır:

“[...] Biz bu işten bir kazanç sağlamadiğımız için sadece sevenleri okusun istiyoruz.” (T.Ç. 2)

3 numaralı tara-çevirmen ise yanıtında telif hakları çerçevesinde açık erişim ilkesinin altını şu sözleriyle çizmektedir:

"Olabildiğince etiğe uygun hareket ediyoruz [...]. Yapacağımız manga \& anime raw olarak veya fansub sitelerinden izin alp temin ediyoruz. Bu çeviriler için de böyle oluyor.” (T.Ç. 3)

4 numaralı tara-çevirmenin ifadesine gelindiğinde ise, tara-çeviri pratikleri etrafında örülen kültürlerarası diyalog ağlarının önemi üzerinde durulmaktadır:

"Kafama takılan bir konu değil, Türkçe basıldı da biz mi almadık? One Piece'in 9 cildi yayımlandı Türkiye'de, bende hepsi var. Bizim sayemizde tanıtımı yapılmış oluyor, bir nevi kültür ateşesi sayılırız." (T.Ç. 4)

$\mathrm{Bu}$ soru kapsamında elde edilen son yanıt çerçevesinde, 5 numaralı tara-çevirmen, çevrimiçi ve çevrimdışı üretim sahaları arasındaki ilişkiselliğe dikkat çekmekte ve tara-çeviri pratiklerinin, çevrimdışı manga yayıncılı̆̆ üzerindeki itici gücünü gündeme taşımaktadır:

“Türkiye’de bu kısmi manga satışını başlamasının yegane sebebi bizim gibi gruplardır. Ve bu tüm dünya için geçerlidir, bu yeni pazara potansiyel müşteri katanlar bizler iken yakın gelecekte gelip bize birinin dur diyeceğini hiç zannetmiyorum”. (T.Ç. 5)

\subsection{Etik sorunlar ve nedenleri üzerine}

İkinci soru kapsamında, tara-çevirmenlerin tara-çeviri içeriklerini üretirken deneyimledikleri etik sorunsalların neler oldukları sorgulanmakta ve bunların önlenebilmesi için tara-çeviri topluluklarının uyguladıkları denetim mekanizmaları üzerinde durulmaktadır. Bu bağlamda, tara-çevirmenlerin tespit ettikleri etik sorunsallar ve bunlara yönelik çözüm önerileri aşağıda yer verilen farklı başlıklar altında değerlendirilmektedir7.

- Kopyala yapıştır tarzı içerik paylaşımı

İlk aşamada, 1 numaralı tara-çevirmen kopyala yapıştır tarzı içerik paylaşımı sorunsalına aşağıda yer alan ifadesinde yer vermektedir (bkz. Şekil 2):

"[...] Hatta başkalarını da bizim işlerimizi kullanmaya elimizden geldiğince teşvik ediyoruz. Yeter ki bize bir selam göndermeyi ihmal etmesinler [...].” (T.Ç. 1)

Gerek görüldüğü takdirde, ilgili tara-çevirmenlerin ürettikleri söylemler yer aldıkları tara-çeviri topluluklarındaki görsel içeriklerle desteklenmektedir. 


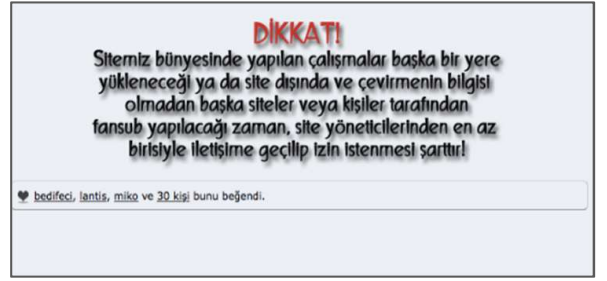

Şekil 2. AnimeManga Topluluğu (www.animemanga.tr)

Devam edildiğinde, 2 numaralı tara-çevirmen, tara-çeviri topluluğu ile tara-çevirmene ve tara-editöre ilişkin dijital kimlik bilgilerinin görünür olması gerektiğinin altını çizmektedir (bkz. Şekil 3):

\section{[...]Çevirilerimizi paylaşmama gibi bir kaprisimiz yok. Tek istediğimiz paylaş̧llrken grubumuzun} ve bizlerin isimlerini yazdığı sayfanın çıarılmaması.”(T.Ç. 2)

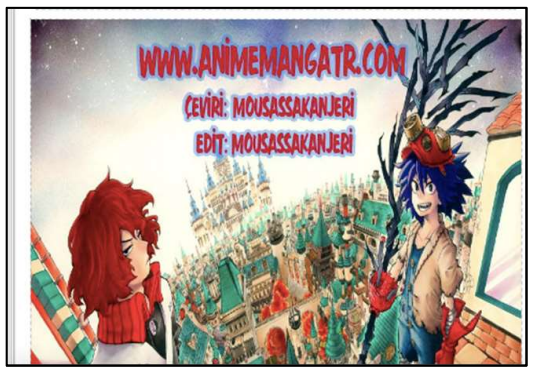

Şekil 3. Sensei No Bulge başlıklı tara-çeviri içeriği (dış kapak)

(http://www.animemangatr.com/forum/manga/Sensei)

- Tara-çeviri içeriğine ilişkin yanıltıcı etiketleme

Aynı soru ekseninde devam edildiğinde, 3 numaralı tara-çevirmen içeriğe ilişkin yanıltıcı etiketleme sorunsalını şu sözleriyle gündeme taşımaktadır (bkz. Şekil 4):

“[...] Bir başkasının yaptığını kendin yapmışsın gibi lanse etmeyi kınamak da bunlardan birisi. Bunu yapan gruplar yaptığı anlaşıldiğı anda prestij ve takipçi kaybederler. Yalnız bize de soranlara dediğimiz gibi, bölümler içine koyduğumuz "credits" denen sayfalar kaldırlmadiğı sürece bu bölümleri paylaşabilirsiniz. Hatta satmadığını sürece yazıcıdan çıkartıp, okuyabilir, matbaada basabilirsiniz [...]. (T.Ç. 3)

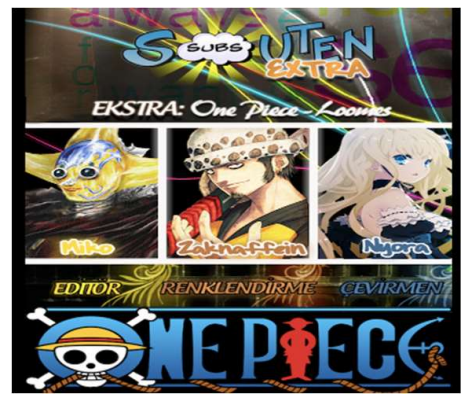

Şekil 4. One Piece başlık tara-çeviri içeriğinin credits $^{8}$ sayfası

8 Tara-çeviri içeriklerinin son sayfasında yer alan credits kavramı, Türkçede emeği geçenler ifadesiyle karşılanabilmektedir (söz konusu kavramın Türkçe çevirisi yazar tarafindan önerilmektedir). 
(http://manga.soutensubs.com/read/one_piece_extra/tr/o/1/page/1)

4 numaralı tara-çevirmen yanlış ve yanıltıcı etiketleme sonucunda yaratılan etik sorunsala şu sözleriyle değinmektedir: (bkz. Şekil 5):

“[...] Sadece ilk sayfada kimin çevirip düzenlediğini gösteren bir credits sayfamız var. Onun dışında serinin yazarı veya çizeri olmadığımı için serinin orijinaline zarar verecek her hangi yazı, logo gibi şeyler basmıyoruz. Ve bu logo basan gruplara karşıyım. Serinin yazarı değilsin çizeri değilsin yayıncısı değilsin ne haddine sadece Türkçeye kazandırdı̆̆ın bir serinin orïinalini bozuyorsun?" (T.Ç. 4)
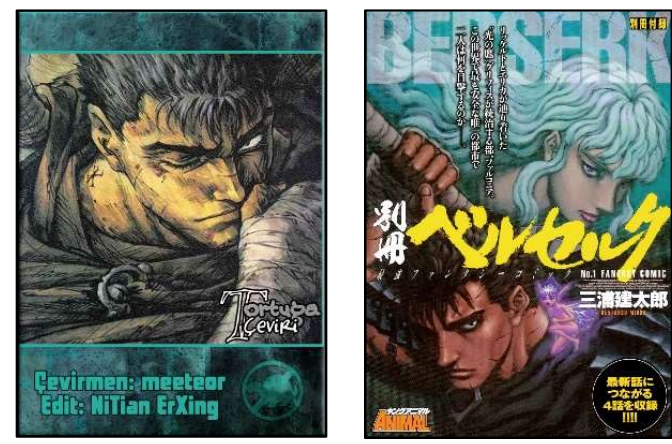

Şekil 5. Berserk başlıklı tara-çeviri içeriği (ön ve arka kapak)

(http://tortuga-ceviri.blogspot.com.tr/p/berserk.html)

- Çevrimiçi telif haklarının ihlali

İçeriğe yönelik telif haklarının ihlali sonucunda başka bir kişinin emeği ile kazanç sağlanması sorununu dile getiren 5 numaralı tara-çevirmenin, bu konuya yönelik dikkat çekici saptaması şu şekildedir (bkz. Şekil 6):

“[...] Hazırladiğımız bölümlerin başka sitelerde paylaşılıp emeğimiz üzerinden para kazanılmasından rahatsızım, emeği harcayan bizken insanların emektar yerine emek hırsızlarına bağış yapması saçmalı̆̆ın daniskası. Bizim çevirdiğimiz anlaşılsın diye kapak ve bitiş sayfalarına sitenin adın yazıyorum; fakat sanırım herkesin dikkatini çekmiyor ki bu kanaatin benden oluşmasının sebebi de bize minnet edilecek yerde bu emek hirsızlarına şükran sunulmasıdır.” (T.Ç. 5)

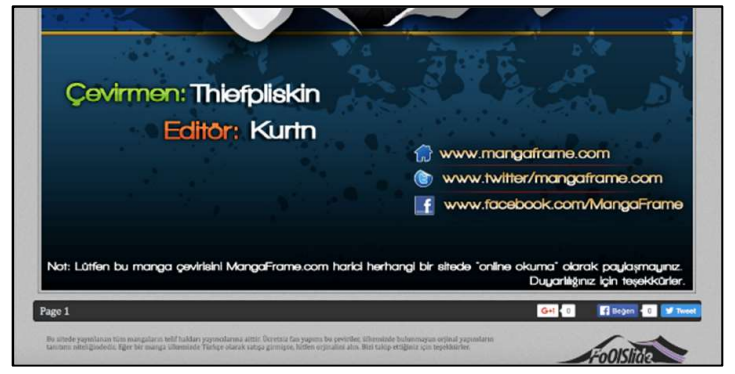

Şekil 6. Mangaframe topluluğu

(http://oku.mangaframe.com/read/arslann_kahramanlk_) 
Araştırma örneklemini oluşturan tara-çevirmenler, yukarıda sözü edilen tara-çevirilerin üretim, dolaşım ve tüketim süreçlerini çevreleyen etik sorunsalları gündeme taşıdıktan sonra, ilgili taraçevirmenler bunların temelinde yatan koşullara yanıtlarında değinmektedirler. Bu çerçevede, taraçevirmenlere göre çevrimiçi iletişim ağının yeniliği, bu ortamlara ilişkin alternatif hukuksal düzenlemelerdeki boşluklar ve bu gibi dijital uygulamalara yönelik kullanıcıyı bilinçlendirecek eğitici yöntemlerin süreklilik kazanmaması, bu yöndeki etik sorunsalları tetikleyen koşullardır. Bu soru kapsamında, tara-çevirmenlerin ifadelerinde öne çıkan vurgu noktaları şu şekildedir:

- Hukuki nedenler

Yeni medyadaki etik sorunların kökeninde yer alan hukuksal düzenlemelerdeki boşluklara ilişkin 1 numaralı tara-çevirmenin değerlendirmesi şu şekildedir:

"[...] Türkçede manga yayımı daha yeni başlad, henüz mangaların İnternet üzerinde Türkçe yayımlarıyla ilgilenen avukat falan da yoktur herhalde [...]”. (T.Ç. 1)

Aynı doğrultuda devam edildiğinde, yeni medya temelli içerikleri koruma altına alan telif ve patent hakları kanunlarının geliştirilmesi konusuna dikkat çeken 2 numaralı tara-çevirmenin ifadesi aşağıdaki gibidir:

“[...] Ĕğer o kadar istiyorlarsa bu tür şeylerin telif hakkına uygun olarak yapılmasını sağlasmlar. Bizim gibi çeviren arkadaşlar iş imkanı sağlasınlar ki biz de temiz temiz herkesten önce çevirip editleyip verelim.” (T.Ç. 2)

Hukuksal düzlemdeki boşluklara odaklanan 3 numaralı tara-çevirmenin bu yöndeki tespiti şu sözlerle ifade etmektedir:

“[...] Bu konuyla ilgili hukuksal bir düzenleme yok ki! O yüzden biraz mecburi olarak korsan yapıyoruz bu işi.”(T.Ç. 3)

- Kültürel nedenler

Tara-çevirmenler tarafından tartışılan bir diğer önemli sorun kaynağı, yeni medya ortamlarında kullanıcıların kişisel haklarına yönelik koruma ve kullanma konusundaki bilinç eksikliği kavramıyla açıklanabilmektedir. Bu çerçevede, 1 numaralı tara-çevirmenin yanıtındaki vurgu noktaları şunlardır:

"[...] Genel olarak her ne kadar internet birinin bir şeyi çok rahat bir şekilde kopyalamasına olanak sağlasa da, manga ortamında yazısız bazı kurallar var. Tabi bu kuralları bilen kaç kişi var! Düşünmeden kullanıyoruz içerikleri...”(T.Ç. 4)

Yeni medya temelli iletişim ağlarına yönelik bireyin farkındalık düzeyinin henüz gelişmediğini sözlerine ekleyen 5 numaralı tara-çevirmenin bu yöndeki düşünceleri şu şekildedir:

[[...] Bence bizim toplumumuzda sorun dijital ortamı kullanmayı bilmemizden kaynaklanıyor. İnsanlarımızın eğitilmesi lazım. Sadece Türkiye’nin her köşesine internet kabloları döşemek, erişim sağlamak yeterli değil.” (T.Ç. 5)

\section{3. Çözüm önerileri üzerine}

Yeni medyadaki etik sorunsalların kökenlerine ilişkin değerlendirmelerin ardından, bu yönde gelişen etik tehditler karşısında ne tür müdahalelerin kim ve kimler tarafından yapılacağına ilişkin tartışmayla devam edilmektedir. 5 numaralı tara-çevirmen bu soruya cevap vermemiştir. Tara-çevirmenlerin, bu 
doğrultuda paylaştıkları görüşlerinde, “özdenetim”, "eleştirel yeni medya okuryazarlı̆̆ı” ve "ortak iletişim etiği” gibi odak noktaları öne çıkmaktadır.

Aşağıdaki ifadesinde, 1 numaralı tara-çevirmen bu süreçte özdenetim becerisi ile etik sorumluluk geliştirme pratiğine ve aynı zamanda muhakeme yetisinin gelişmesine dikkat çekmektedir:

"[...] X mangasın haklarım elinde bulunduran firma yarın bizimle iletişim kurup çevirilerimizi kaldırmamızı isterse kaldırırız. Ama o güne kadar elimizden geldiğince çeviri yapıp sevenlerinin okumasımı sağlamak istiyoruz [...].” (T.Ç. 1)

Özdenetimsel kavrayışın önemini ortaya koyan bir diğer tara-çevirmenin bu doğrultudaki tespiti aşağıdaki gibidir:

"[...] İstesem internet üzerinden çevirip satışları etkileyebilirdim., ama böyle şeylere ihtiyaç duymam, hem de ayıp denen bir şey var.” (T.Ç. 2)

Kullanıcıyı bilinçlendirecek yöntemler geliştirilmesi gerektiğine ilişkin söylemiyle öne çıan 3 numaralı tara-çevirmen, bireyin eleştirel yeni medya okuryazarlı̆̆ı yetisiyle donatılmasının altı çizmektedir:

“[...] Kullanıcıya farkındalık kazandırmak bu sorunları bir nebze çözebilir. İnternet okurunun mesela fan topluluklarından talep etmesi gerekiyor. Yani şöyle demek istiyorum, ben internetten manganın çevirisini okurken ilk sayfada orïinal manganın hangisi olduğunu görmek istiyorum.

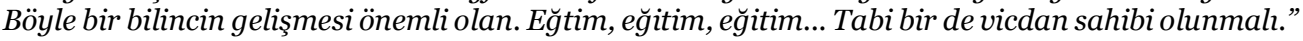
(T.Ç. 3)

Yeni medyadaki etik sorunlara ilişkin sorumlu tarafları tespit eden ve çözüm önerileri sunan 4 numaralı tara-çevirmen söyleminde, yeni medya ortamlarına ilişkin tüm tarafların katılımıyla geliştirilmesi gereken ortak iletişime dayalı etik yaklaşımın önemi üzerinde durmaktadır:

"[...] Ayrıca biz çok isteriz yaptı̆̆ımız işin daha fazla ses getirmesini. Hukuki düzenlemeler bizi korkutmaz. Tam aksine yayınevleri, devlet kurumları, avukatlar bu işi bilen herkesle ortak çalışmalar yapmaya hazırız. Sonuçta ortada bir emek var. Kimse zarar görsün istemeyiz.” (T.Ç. 4)

Görüldüğü üzere, ilgili tara-çevirmenlerin, tara-çeviri pratikleri ile yeni medya etiği arasındaki ilişkiselliği sorguladıkları yanıtlarında, kavramsal ve yöntemsel anlamda çeviri etiğine yönelik yeni sorgulamaların ve yeni düşünce biçimlerinin üretildiği sonucuna ulaşılmaktadır.

\section{Sonuç}

Japon ruhuyla Batı tekniğinin etkileşimi sonucunda gelişen ve Japonya'nın yumuşak gücünü temsil eden Japon çizgi roman sanatı manga, küreselleşme hareketiyle birlikte dijital ağlarda yeniden üretilmektedir. Sanal deneyimler etrafında inşa edilen tara-çeviri pratikleri ve tara-çevirmen kimlikleri dikkat çekici niteliktedir. İlgili araştırma kapsamında, söz konusu tara-çevirmenlerin çeviri etiğine ilişkin yapı ve süreçleri nasıl deneyimledikleri ve onlarla nasıl bir çeviri etiği hareketi inşa ettikleri üzerine netnografik bir çözümleme gerçekleştirilmiştir.

Tara-çevirmenler, tara-çeviri içeriklerinin dolaşımını yönlendiren koşullara yönelik ortaya çıkan etik sorunların kökenini, alanının yeniliğinden kaynaklanan kullanıcı temelli bilinç eksikliğiyle ilişkilendirmişlerdir. Üreten tüketici konumundaki kullanıcının, yeni medya temelli üretim pratikleri bağlamında sahip olduğu yetki ve sorumluluk alanlarına yönelik bilinç eksikliği, ilgili tara-çevirmenler tarafından her defasında vurgulanmıştır. Bunun yanı sıra, tara-çevirmenler hukuksal düzlemde bu 
süreçleri düzenleyen alternatif yasalara ihtiyaç duyulduğunu görüşlerinde bildirmişlerdir. Taraçevirmenlerin bu yöndeki tespitleri, yeni medya etiği kapsamında deneyimlenen sorunsalları, bunlara kimler tarafından, hangi yöntemlerle müdahale edileceğine dair tartışmaları da gündeme taşımıştır. Bu bağlamda, bireyin, özdenetime dayalı etik sorumluluk ve muhakeme yetisinin geliştirilmesi ile eleştirel yeni medya okuryazarlığına ilişkin çeşitli bilgi ve becerilerle donatılması, saha çalışmasından elde edilen diğer sonuçlar arasındadır. Bu noktada, tara-çevirmenlerin dikkat çektikleri bir diğer unsur ise tara-çeviri hareketlerinde yaşanan etik sorunlar karşısında, bu süreci deneyimleyen tüm aktörlerim görüşlerine başvurularak ortak çözüm mekanizmalarının üretilmesinin gerekliliğidir. Bir başka deyişle, tara-çevirmenler etik anlamda sorumluluğun çok katmanlı ve çok aktörlü olduğu gerçeğine vurgu yapmışlardır. Tara-çeviri içeriklerinin gönüllülük, açık erişim hakkı ve kültürlerarası diyaloğun desteklenmesi gibi üretim ve tüketim koşullarıyla çerçevelendirilmesi, tara-çevirmenlerin bu doğrultuda benimsedikleri etik duruşlarını açıklamaktadır.

Dijital ortamda yükselen tara-çeviri hareketleri, çeviri etiği kapsamında yeni sorgulama biçimlerini ve yeni kavramsallaştırmaları, en önemlisi de çevrimiçi sahanın sesini, çevrimdışına taşıyan yeni yaklaşımları gündeme taşımaktadır. Söz konusu olan tara-çeviri hareketlerinin etik sonuçlarını açılamak için, yeni medyadaki üretim ve tüketim koşulları göz önünde bulundurularak varolan çeviri etiği kuramlarının ve yaklaşımlarının yeniden yapılandırılması gündeme gelmektedir Bu süreçte, amatör ve profesyonel çevirmeni karşı karşıya getirecek kutuplaştırıcı, ayrıştırıcı yaklaşımlardan kaçınılması, gönüllü, amatör ve fan çevirmenlerin görünürlük kazandığı ve seslerinin duyulduğu ya da başka bir deyişle söz konusu çevirmenlerin pasifleştirilmediği ve demokratik bir şekilde alana katılma cesaretlerinin ve motivasyonlarının desteklendiği bilimsel üretim platformlarının inşa edilmesi oldukça önemlidir. İlgili tara-çeviri pratikleri odağında yapılan netnografik çözümleme sonucunda, algoritmaların ve sanal deneyimlerin çeviri etiğini yeniden inşa ettiğine tanık olunmaktadır.

Katılımcı ve paylaşımcı bir çeviri etiği anlayışını benimseyen tara-çevirmenlerin etik sorunlar karşısında kısıtlayıcı, sınırlandırıcı, baskıcı yasalara başvurmak yerine, ilgili aktörlerin üretim pratiklerinde ve performans sergileme biçimlerinde, yeni medya etiği bilincinin yerleştirilmesine yönelik girişimlerde bulunmaları, araştırmanın dikkat çekici sonuçları arasında yer almaktadır. Yeni medya ağlarının siber suçları ve gözetimi artırma gibi içerisinde barındırdığı tehditler karşısında moral panik yaratmak yerine yeni medya ortamlarında çevirmenin hak ve özgürlüklerinin bilinmesine ve mahremiyetinin korunmasına ilişkin hukuksal düzenlemelere ve yasalara rehberlik edecek etik ilkelerin geliştirilmesi, tara-çevirmenler tarafından her defasında vurgulanmaktadır. Sonuç olarak, ortak iletişim etiği, açık etik yapma, özdenetimsel anlayıs, yeni medya okuryazarhğı ve etik muhakeme becerisi gibi yeni medya etiğine ilişkin kavramlar etrafında üretilen tara-çeviri pratikleri ve tara-çevirmen kimlikleri, çevrimdışı çeviri dünyasındaki etik yaklaşımların ve kuramların nasıl yeniden inşa edilebileceğine dair bir nebze de olsa katkı sunmaktadır.

\section{Kaynakça}

Aydın, B. (2007). Manga: Çizgi Roman Meraklıları İçin Bir Giriş. Sanat Dünyamız, 105, 9-29.

Binark, M. (2014). Yeni Medya Çalş̧malarında Araştırma Yöntem ve Teknikleri. İstanbul: Schola Ayrinti.

Binark, M. ve Bayraktutan, G. (2013). Ayın Karanlı Yüzü: Yeni Medya ve Etik. İstanbul: Kalkedon.

Bouissou, J. M. (2006). Japan's Growing Cultural Power: Manga in France. Berndt J., Richter S. (Ed.),

Reading Manga: Local and Global Perceptions of Japanese Comics içinde (s. 149-165). Leipzig: Leipziger Universitätsverlag. 
Fernández-Costales, A. (2011). Translation 2.0: Facing the Challenges of the Global Era. Proceedings from Tralogy, 1-12.

Fernández-Costales, A. (2012). Collaborative Translation Revisited: Exploring the Rationale and the Motivation for Volunteer Translation. Forum, 10(1), 115-142.

Demirel Bogenç, E., Görgüler Z. (2015). Pratique réflexive sur la traduction collaborative en ligne en Turquie. 100\% User-made translation. Revue Parallèles, 27, 137-148.

Demirel Bogenç, E., Görgüler, Z. (2019). Traduction dans les réseaux sociaux. Nouvelles pratiques traductives en Turquie. Des mots aux actes, (8), 271-288.

Dolmaya, M. J. (2012). Analyzing the crowdsourcing model and its impact on public perceptions of translation. The Translator, 18(2), 167-191.

Gambier, Y. (2009). Competences for professional translators, experts in multilingual and multimedia communication. European Master's in Translation-EMT, 1, 1-7.

Görgüler, Z. (2016). "Yeni Toplumsallıklar Etrafinda Yükselen Çeviri Pratikleri: Türkiye’de Tara-Çeviri (Manga) İçeriklerinin Dolaşımı ve Netnografik Çözümlemeler”, Doktora Tezi (Yayımlanmamış), Yıldız Teknik Üniversitesi Sosyal Bilimler Enstitüsü.

Gravett, P. (2008). Manga Japon Çizgi Romanının Tarihi. Çev: Rüstem Baksoy. İstanbul: Plan B.

Kozinets, V. R. (2006). Click to Connect: Netnography and Tribal Advertising. Journal of Advertising Research, 46(3), 279-288.

Niedzvieck, H. (2010). Dikizleme Kültürü. Çev. Gökçe Gündüç. İstanbul: Ayrıntı.

O’Hagan, M. (2009). Evolution of User-Generated Translation: Fansubs, Translation Hacking and Crowdsourcing. Journal of Internalization and Localisation 1(1), 94-121.

O'Hagan, M. (2011). Introduction : Community translation: Translation as a social activity and its possible consequences in the advent of Web 2.0 and beyond. Linguistica Antwerpensia, 10, 11- 2

O’Hagan, M. (2016). Massively Open Translation: Unpacking the Relationship Between Technology and Translation in the $21^{\text {st }}$ Century. International Journal of Communication, 10, 929-946.

Pérez-González, L. (2010). Ad-hocracies of translation activism in the blogosphere: A genealogical case study. Mona Baker, Maeve Olohan, Maria Calzade Pérez (Ed.), Text and Context: Essays on Translation and Interpreting in Honour of Ian Mason içinde (s. 259-287). Manchester: St Jerome.

Pérez-González, L., Susam-Saraeva Ş. (2012). Non-professionals translating and interpreting: Participatory and engaged perspectives. The Translator 18(2), 149-165.

Pym, A. (2014). Translator associations-from gatekeepers to communities. Target 26(3), 466-491.

Rampant, J. (2010). The Manga Polysystem: What Fans Want, Fans Get. Manga. Toni Johnson-Wood (Ed.), An Anthology of Global and Cultural Perspectives içinde (s. 221-232). London: Continuum.

Uzun, R. (2013). Ayın Karanlı Yüzü: Yeni Medya ve Etik içinde (arka kapak), Mutlu Binark ve Güneş Bayraktutan (Ed.). İstanbul: Kalkedon.

\section{Çevrimiçi kaynaklar}

http://animemangatr.com [Erişim tarihi: Şubat 2016]

http://mangaframe.com [Erişim tarihi: Şubat 2016]

http://manga.soutensubs.com [Erişim tarihi: Şubat 2016]

http://tortuga-ceviri.blogspot.com.tr [Erişim tarihi: Şubat 2016] 